\title{
Uji Beda Ekspor dan Import Indonesia-China Sebelum dan Sesudah Pandemi Covid-19
}

\author{
Rivatul Ridho Elvierayani, Sukmawati Indah Dzikriah, Rachma Dwi Arifani' Rifqi \\ Afriyandani \\ Universitas Islam Lamongan, Indonesia \\ Email corresponding author: rivatulridho@unisla.ac.id
}

\begin{abstract}
ABSTRAK
Saat ini dunia digemparkan dengan penyebaran wabah Virus Corona yang berasal dari Wuhan China.Penelitian ini bertujuan untuk mengetahui apakah terdapat perbedaan ekspor dan impor Indonesia terhadap China sebelum dan sesudah Pandemic Covid-19. Lokasi penelitian dilakukan pada Badan Pusta Statistik dengan menggunakan data ekspor dan impor periode Mei 2019-Desember 2020 dengan pertimbangan sepuluh bulan sebelum dan sepuluh bulan sesudah terjadinya pandemic covid-19. Penelitian menggunakan pendekatan kuantitatif dengan melakukan statistic deskriptif dan statistika inferensial. Uji ipotesis dalam penelitian ini menggunakan uji t berpasangan (paired sample t test) sebagai uji beda. Sebelum melakukan uji beda terlebih dahulu dilakukan uji normalitas untuk mengetahui data yang digunakan berdistribusi normal atau tidak. Hasil uji t berpasangan (paired sample t test) menunjukkan bahwa tidak terdapat perbedaan ekspor Indonesia ke China sebelum dan sesudah pandemic Covid-19.Sama halnya dengan kegiatan eksport, hasil uji t berpasangan (paired sample t test) menunjukkan bahwa tidak terdapat perbedaan import Indonesia dari China sebelum dan sesudah terjadinya pandemic Covid-19.
\end{abstract}

Kata Kunci: Pandemic Covid-19, ekspor, impor

\section{ABSTRACT}

Currently the world is shocked by the spread of the Corona Virus outbreak which originated in Wuhan China. This study aims to determine whether there are differences in Indonesia's exports and imports to China before and after the Covid-19 Pandemic. The location of the research was carried out at the Pusta Statistics Agency using export and import data for the period May 2019-December 2020 with the consideration of ten months before and ten months after the covid-19 pandemic. This research uses a quantitative approach by doing descriptive statistics and inferential statistics. The hypothesis test in this study used paired sample t test as a test of difference. Before doing a different test, first a normality test is carried out to determine whether the data used is normally distributed or not. The paired sample t test results show that there is no difference in Indonesia's exports to China before and after the Covid-19 pandemic. Similar to export activities, the paired sample t test results show that there is no difference in Indonesia's imports from China before and after the Covid-19 pandemic.

Keywords: Pandemic Covid-19, export, import

\section{PENDAHULUAN}

Keterbatasan sumber daya dan kebutuhan penduduk yang semakin meningkat membuat sebuah Negara sulit untuk memenuhi seluruh kebutuhannya sendiri, sehingga membutuhkan kerjasama dengan Negara-negara lain. Hal inilah yang menjadi alasan sebuah Negara untuk 
melakukan perdagangan Internasional dengan Negara lain. Perdagangan internasional dalam sebuah Negara sangat penting untuk dilakukan agar mampu menyokong kondisi kestabilan perekonomian suatu Negara.Banyak manfaat yang dirasakan dengan adanya perdagangan internasional, tidak hanya Negara saja namun lebih pada sisi kebutuhan manusia itu sendiri.

Negara Indonesia aktif dalam perdagangan internasional dengan melakukan kegiatan ekspor dan impor.Indonesia juga melakukan usaha untuk meningkatan perkenomian dengan bergabung secara aktif dalam hubungan kerjasama antar Negara yang tegabung dalam suatu kelompok kesepakatan kerjasama perdagangan baik multilateral maupun regional.Ada sejumlah organisasi kerjasama di bidang ekonomi yang dipelopori oleh Indonesia diantaranya AFTA dan APEC (Welianto, 2020).

Ekspor merupakan penjualan barang atau jasa yang diproduksi di dalam negeri ke luar negeri.Ekspor yang tinggi juga mengakibatkan tenaga kerja suatu negara terserap secara penuh sehingga pengangguran berkurang dan meningkatkan pendapatan perkapita negara tersebut sehingga daya beli meningkat.Impor adalah pembelian barang dari luar negeri ke dalam negeri. Nilai impor yang tinggi akan menurunkan produksi di dalam negeri akibatnya tenaga kerja mengalami pemutusan kerja dari pihak perusahaan dan pengangguran meningkat serta pendapatan menurun sehingga daya beli masyarakat juga akan menurun.

Sejak awal tahun 2020, dunia dihebohkan dengan adanya wabah virus corona yang berasal dari China.Virus corona menyebabkan kepanikan di China dan menimbulkan korban jiwa sampai ribuan orang penduduk China.Akibat lainnya, banyak perusahaan kecil, menengah maupun besar yang akhirnya terpaksa menutup usahanya untuk sementara.Tidak hanya perusahaan saja yang tutup, ribuan tempat usaha makanan/ minuman juga terpaksa tutup. Perekonomian China pun menjadi terguncang di awal tahun 2020 ini, karena selama ini perekonomian China didukung dari sektor usaha kecil dan menengah. Ada sekitar 30 juta usaha kecil dan menengah menyumbang lebih dari 60\% dari Produk Domestik Bruto (PDB) China (merdeka.com., 18 Februari 2020). Dengan melihat kondisi perekonomian China saat ini, banyak analis yang memprediksi pertumbuhan ekonomi China dapat turun mendekati angka 5\% di tahun 2020.Industri yang paling terkena dampaknya adalah industri manufaktur dan pariwisata.Seperti kita ketahui, Kota Wuhan di mana tempat awal mula wabah virus corona terjadi, merupakan pusat industri otomotif di China. Kontribusi Kota Wuhan terhadap perekonomian China mencapai 1,6\% (katadata.co.id, 7 Februari 2020). Tidak hanya China semua Negara mengalami dampak ekonomi tak terkecuali Indonesia juga mengalami dampak tersebut termasuk kegiatan ekspor dan impor baik ke Chna maupun ke Negara-negara lainnya. Menurut Hamdani (2012:24) ekspor adalah "kegiatan pengeluaran barang dari daerah pabean." Kegiatan ekspor merupakan sistem perdagangan dengan mengeluarkan barang-barang dari dalam negeri ke keluar negeri dengan memenuhi ketentuan yang berlaku.Menurut UndangUndang No.10 Tahun 1995 tentang Kepabeanan, "impor adalah kegiatan memasukkan barang ke dalam daerah pabean.'Kegiatan impor ialah kegiatan jual beli yang melibatkan antara penjual dan pembeli di negara yang berbeda yang merupakan bagian dari perdagangan internasional.

Ekspor dan impor merupakan kegiatan yang sangat penting bagi sebuah Negara. Dari kegiatan ekspor dan impor sebuah Negara akan memperoleh pendapatan. Namun, saat ini seluruh dunia sedang dihadapkan dengan pandemic Covid-19 yang terus meluas.Pandemi ini berdampak pada banyak sector, termasuk perekonomian Negara.Banyak Negara mebmberlakukan lockdown yang mempengaruhi kegatan ekspor dan impor.Berdasarkan data statistik yang dikeluarkan oleh Badan Pusat Statistik (BPS), pandemi Covid-19 ini juga berdampak terhadap impor migas dan non migas Indonesia pada periode Januari hingga Juni 2020. Pada kurun waktu tersebut kegiatan impor khususnya non migas mengalami fluktuasi.

Berdasarkan data pada Badan Pusat Statistik (BPS) tahun 2020 mencatat bahwa ekspor non migas utama Indonesia masih tertuju pada Tiongkok sekitar $17,04 \%$, tak hanya ekspor, 
Tiongkok juga Negara asal produk impor yang mendominasi mencapai $28,13 \%$ yang disusul oleh Jepang sebesar 10,04\%, lalu Singapura sebesar 6,59\%, Thailand sebesar 6,19\%, dan Thailand sebesar 5,93\% (Perdana, 2020).

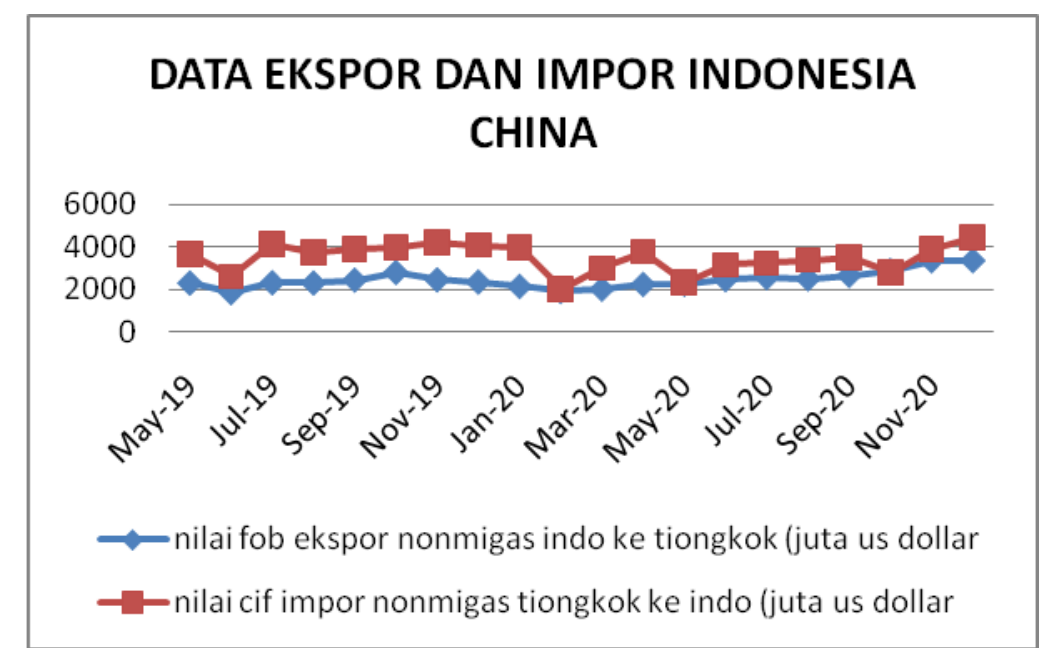

Gambar 1. Grafik Nilai Ekspor dan Impor Non migas Indonesia China

Grafik diatas menunjukkan angka nilai ekspor dan impor non migas Indonesia terhadap China yang fluktuatif setiap bulannya.

Berdasarkan data statistika yang dikeluarkan oleh BPS, pada kurun waktu selama beberapa bulan terakhir (Mei 2019-Desember 2020) peneliti ingin mengamati apakah terdapat perbedaan yang signifikan aktifitas ekspor dan impor Indonesia China sebelum dan sesudah terjadinya pandemic Covid-19 pada sektor non migas seneliti merumuskan beberapa hipotesis di bawah ini:

$\mathrm{H}_{1}=$ Terdapat perbedaan ekspor Indonesia ke China sebelum dan sesudah terjadinya pandemic Covid-19

$\mathrm{H}_{2}=$ Terdapat perbedaanimpor Indonesia dari China sebelum dan sesudah perang terjadinya pandemic Covid-19

\section{METODE PENELITIAN}

\section{Jenis Penelitian}

Jenis penelitian ini merupakan penelitian event study (studi peristiwa), yang digunakan untuk mengamati dampak dari suatu peristiwa terhadap variabel lainnya.Peneliti menggunakan penelitian event study dikarenakan penelitian event study sesuai dengan tujuan penelitian ini, yaitu untuk mengetahui dan menjelaskan perbedaan ekspor dan impor Indonesia terhadap China.

\section{Populasi dan Sampel}

Populasi yang digunakan dalam penelitian ini berasal dari data ekspor dan impor Indonesia terhadap China.Penelitian ini menggunakan sampel yang didasarkan pada purposive sampling yang sesuai degan kriteria yang telah ditentukan. Kriteria yang digunakan dalam pemilihan sampel adalah sebagai berikut:

1. Data per bulan ekspor dan impor

2. Data per bulan ekspor dan impor Indonesia terhadap Tiongkok (China)

3. Periode Mei 2019- Desember 2020 
Sesuai dengan kriteria pemilihan sampel diatas, terdapat masing-masing 20 sampel data ekspor dan impor Indonesia terhadap China periode Mei 2019 sampai Desember 2020.Sampel tersebut terbagi menjadi dua kelompok sampel, yaitu kelompok sampel pertama, sebelum terjadi covid19 terdiri dari data per bulan periode bulan Mei 2019 hingga Februari 2020 (10 bulan), sehingga berjumlah 10 data.Kelompok sampel kedua, setelah terjadi PandemiCovid-19 terdiri dari data per bulan periode bulan Maret 2020 hingga Desember 2020 (10 bulan), sehingga berjumlah 10 data.

\section{Teknik Analisis Data}

Teknik analisis yang digunakan dalam penelitian ini menggunakan pendekatan kuantitatif yang menggunakan statistik. Berikut adalah statistik yang digunakan untuk menganalisis data dalam penelitian ini:

1. Statistik Deskriptif Tahap ini peneliti akan melakukan pengujian statistik dengan menguji nilai ekspor dan impor Indonesia dengan China sebelum dan sesudah terjadinya pandemi covid-19. Pengujian menggunakan perhitungan nilai maximal, minimal, mean, dan standard deviation.

2. Statistik Inferensial Menurut Sudijono (2008:4), "Statistik inferensial adalah statistik yang menyediakan aturan atau cara yang dapat dipergunakan sebagai alat dalam rangka mencoba menarik kesimpulan yang bersifat umum, dari sekumpulan data yang telah disusun dan diolah." Penelitian akan dilakukan dengan uji hipotesis dengan menggunakan uji beda yang disesuaikan dengan sampel penelitian ini, yaitu sampel berpasangan. Terdapat dua uji beda yang digunakan sebagai uji hipotesis dalam penelitian ini. Uji parametrik yaitu uji t perpasangan (Paired sample $t$ test) dan uji non parametrik yaitu uji peringkat bertanda Wilcoxon (Wilcoxon signed ranks test). Sebelum melakukan uji beda, uji normalitas dilakukan terlebih dahulu. Hal ini dikarenakan pemilihan uji beda yang digunakan akan ditentukan berdasarkan hasil dari uji normalitas. Data berdistribusi normal menggunakan uji parametrik dan data tidak berdistribusi normal menggunakan uji non parametrik.

a. Uji Normalitas Uji Kolmogorov-Smirnov digunakan untuk menguji normalitas data. Dasar pengambilan keputusan dalam uji ini ditentukan dengan melihat nilai signifikannya. Apabila nilai sig. > 0,05 maka data tersebut berdistribusi normal, dan sebaliknya apabila nilai sig. $<0,05$ maka data tersebut tidak berdistribusi normal.

b. Uji t Berpasangan (Paired Sample t Test) Uji t berpasangan merupakan uji parametrik yang sesuai dengan tujuan penelitian ini, yakni untuk menganalisis ada tidaknya perbedaan pada sampel berpasangan. Rumus uji beda $t$ berpasangan adalah sebagai berikut:

$$
t=\frac{\text { Ratarata sampel pertama-Ratarata sampel kedua }}{\text { Standart error perbedaan rata }- \text { rata kedua sampel }}
$$

Sumber: Ghozali (2013)

Kriteria pengambilan keputusan pada uji ini adalah sebagai berikut:

1) Ho diterima apabila: $t$ hitung $\leq t$ tabel atau Sig. $>0,05$.

2) Ha diterima apabila: $t$ hitung $>t$ tabel atau Sig. $\leq 0,05$.

c. Uji Peringkat Bertanda Wilcoxon (Wilcoxon Signed Ranks Test)

Wilcoxon signed ranks test merupakan uji statistika non parametrik yang digunakan untuk menganalisis sampel berpasangan. Wilcoxon signed ranks test digunakan untuk melihat ada atau tidaknya perbedaan dari data sebelum dan sesudah adanya perlakuan tertentu dan digunakan jika data tidak berdistribusi 
normal. Kriteria pengambilan keputusan pada uji ini adalah nilai statistik Wilcoxon <nilai kritis maka H0 ditolak dan H1 diterima, begitupula sebaliknya (Suharyadi dan Purwanto, 2016:350).

\section{HASIL PENELITIAN DAN PEMBAHASAN}

\section{Penyajian Data}

Data bulanan nilai ekspor dan impor Indonesia terhadap China periode sebelum terjadi pandemic covid-19 pada bulan Agustus 2019-Januari 2020 dan sesudah pandemic Covid-19 pada bulan Februari 2020-Juli 2020 mengalami pergerakan fluktuatif setiap bulannya. Nilai ekspor dan impor disajikan dalam bentuk juta dollar AS, sesuai dengan gambar sebagai berikut:

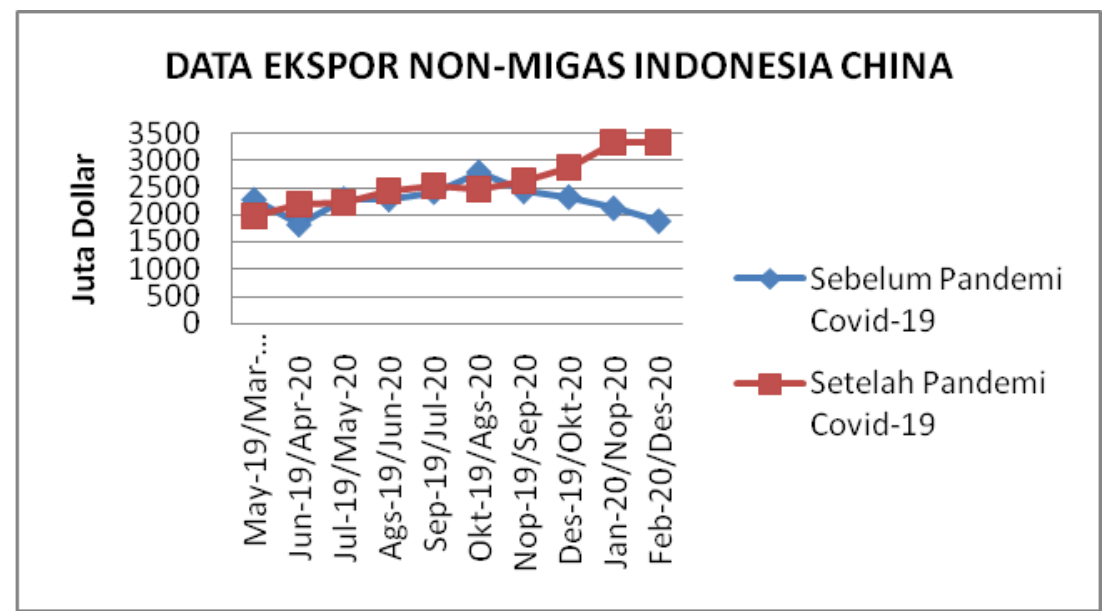

Gambar 2. Pergerakan nilai Ekspor Indonesia Terhadap China

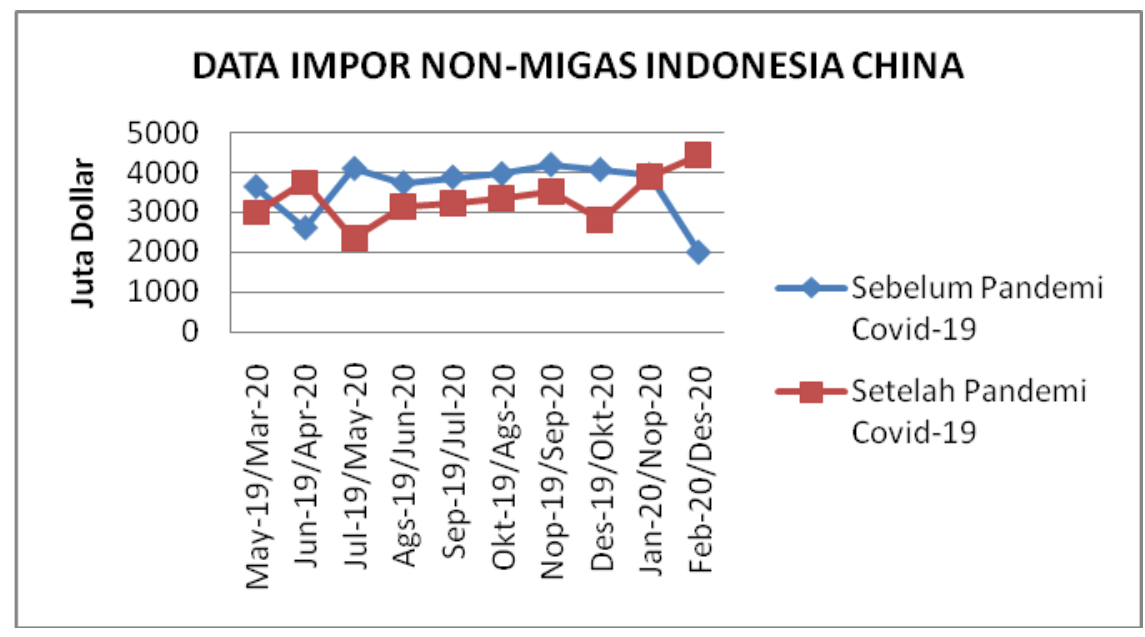

Gambar 3. Pergerakan nilai Impor Indonesia Terhadap China 


\section{Hasil Penelitian}

Uji Normalitas

Tabel 1. Hasil Uji Kolmogorov-Smirnov Ekspor Indonesia Terhadap China

\begin{tabular}{|l|l|l|l|}
\hline & \multicolumn{2}{l}{ Kolmogorov-Smirnov } & \multicolumn{1}{c|}{ Keterangan } \\
\hline Ekspor sebelum & $\mathrm{N}$ & Sig. & Berdistribusi Normal \\
\hline Ekspor Sesudah & 10 & 0,716 & Berdistribusi Normal \\
\hline
\end{tabular}

Tabel 2. Hasil Uji Kolmogorov-Smirnov Impor Indonesia Terhadap China

\begin{tabular}{|l|l|l|l|} 
& \multicolumn{2}{|l}{ Kolmogorov-Smirnov } & \multicolumn{2}{l}{ Keterangan } \\
\hline Impor sebelum & $\mathrm{N}$ & Sig. & Berdistribusi Normal \\
\hline Impor Sesudah & 10 & 0,266 & Berdistribusi Normal \\
\hline
\end{tabular}

Hasil uji normalitas dengan uji KolmogorovSmirnov, semua menujukkan hasil data berdistribusi normal, maka uji hipotesis yang digunakan untuk menganalisis data ekspor dan impor Indonesia terhadap Amerika Serikat dan China adalah uji t berpasangan (Paired sample t test).

\section{Uji t Berpasangan (Paired Sample t Test)}

Tabel 3. Paired Samples Test Ekspor Indonesia ke China Sebelum dan Sesudah Terjadi Pandemi Covid-19

\begin{tabular}{|c|c|c|c|}
\hline \multirow[t]{5}{*}{ Paired Differences } & \multicolumn{2}{|l|}{ Mean } & $-342,0500$ \\
\hline & \multicolumn{2}{|l|}{ Std. Deviation } & 584,4368 \\
\hline & Std. error Mean & & 184,8152 \\
\hline & \multirow{2}{*}{$\begin{array}{l}95 \% \text { Confidence } \\
\text { Interval of the } \\
\text { Difference }\end{array}$} & Lower & $-760,1309$ \\
\hline & & Upper & 76,0309 \\
\hline \multicolumn{2}{|l|}{$\mathbf{t}$} & & $-1,851$ \\
\hline \multicolumn{2}{|l|}{ df } & & 9 \\
\hline \multicolumn{2}{|l|}{ Sig. (2-tailed) } & & 0,097 \\
\hline
\end{tabular}

Hasil pada tabel 3 menunjukkan nilai thitung sebesar -1,851 dengan nilai Sig. sebesar 0,097 > 0,05 yang berarti Ho diterima, yaitu tidat terdapat perbedaan antara ekspor Indonesia ke China sebelum dan sesudah pandemic Covid-19.

Tabel 4. Paired Samples Test Impor Indonesia ke China Sebelum dan Sesudah Terjadi Pandemi Covid-19

\begin{tabular}{|c|c|c|c|}
\hline \multirow[t]{5}{*}{ Paired Differences } & \multicolumn{2}{|l|}{ Mean } & \multirow{2}{*}{$\begin{array}{r}\mathbf{2 6 8 , 4 7 0 0} \\
1221,6250\end{array}$} \\
\hline & Std. Deviation & & \\
\hline & Std. error Mean & & 386,3117 \\
\hline & $95 \%$ Confidence & Lower & $-605,4279$ \\
\hline & $\begin{array}{l}\text { Interval of the } \\
\text { Difference }\end{array}$ & Upper & 1142,3679 \\
\hline \multicolumn{2}{|l|}{$\mathbf{t}$} & & 0,695 \\
\hline \multicolumn{2}{|l|}{ df } & & 9 \\
\hline \multicolumn{2}{|l|}{ Sig. (2-tailed) } & & 0,505 \\
\hline
\end{tabular}


Hasil pada tabel 4 menunjukkan nilai t hitung sebesar 0,695 dengan nilai Sig. sebesar 0,505 > 0,05 yang berarti Ho diterima, yaitu tidat terdapat perbedaan antara ekspor Indonesia ke China sebelum dan sesudah pandemic Covid-19.

\section{Tidak Terdapat Perbedaan Antara Ekspor Indonesia ke China Sebelum dan Sesudah terjadinya Pandemi Covid-19}

Hasil uji hipotesis dengan menggunakan uji beda (Paired Sample test) menunjukkan bahwa dengan terjadinya pandemic covid-19 di Indonesia pada bulan Maret 2020 memberkan hasil bahwa tidak ada perbedaan ekspor Indonesia ke China. Sebab Indonesia hanya menyumbangkan sedikit komoditas produk ekspor ke China dari beberapa negara yang melakukan ekspor pula ke China. Berdasarkan data statistik data menunjukkan penurunan pada awal-awal bulan saat terjadi pandemic Covid-19. Hal ini dikarenakan pembatasan nilai ekspor karena adanya pandemik namun secara statistik tidak ada perubahan secara signifikam nilai ekspor Indonesia ke china baik sebelum maupun sesudah pandemic covid-19.

Sebagai Negara berkembang Indonesia harusnya lebih berusaha untuk melakukan diversifikasi pasar ekspor seperti halnya Negara-negara di China, Afrika atau Amerika Selatan (kompas, 19 Februari 2020) agar nilai ekspor Indonesia dapat semakin merangkak naik untuk memperbesar dan memperluas perdagangan dunia. Selain itu Indonesia juga perlu mengoptimalkan penggunaan produksi dalam negeri agar dapat memenuhi kebutuhan permintaan di pasar domestic dan mulai mengurangi ketergantungan pada barang-barang impor. Hal ini tentu bias di atasi jika peningkatan dan pemberdayaan SDM di Indonesia dilakukan dengan baik dan terarah. Data terbaru menunjukkan bahwa Dalam konferensi pers, Menlu Retno Marsudi menyampaikan angka ekspor Indonesia ke China mengalami peningkatan 11,74 persen pada semester I 2020 (dari US\$ 12,32 miliar menjadi US\$ 13,77 miliar). Ini merupakan semester I 2019 dibanding dengan 2020.Dengan data ini semoga Indonesia dapat memperkokoh perekonomiannya dengan memperkuat perdagangan Internasional.

Hasil penelitian ini sesuai dengan penelitian yang dilakukan oleh Putri \& Suhadak (2019) yang menyatakan bahwa pengaruh perang dagang Amerika Serikat dan China terhadap ekspor dan impor membuktikan bahwa tidak ada pengaruh secara signifikan ekspor Indonesia ke China sebelum dan sesudah terjadinya perang dagang Amerika Serikat dan China karena sedikitnya sumbangsih komoditas prioduk ekspor dari Indonesia ke China. Dan hasil penelitian Rahma (2016) yang menyatakan bahwa pengaruh ASEAN-China Free Trade Area terhadap ekspor dan impor Indonesia-China membuktikan bahwa tidak terdapat pengaruh signifikan dari penerapan ACFTA terhadap ekspor, karena ACFTA belum mampu melaksanakan tujuannya dalam mengurangi hambatan-hambatan untuk meningkatkan ekspor.

\section{Tidak Terdapat Perbedaan Antara Impor Indonesia ke China Sebelum dan Sesudah terjadinya Pandemi Covid-19}

Berdasarkan hasil uji hipotesis dengan menggunakan uji beda (Paired sample test) menunjukkan bahwa dengan terjadinya pandemic covid-19 di Indonesia pada bulan Maret 2020 memberkan hasil bahwa tidak ada perbedaan antara impor Indonesia dari China sebelum dan sesudah terjadinya Pandemi Covid-19. Hal ini di sebabkan karena ketergantungan masyarakat Indonesia yang menggunakan barang-barang produksi dari China semakin menjadi tradisi pasar sehingga meskipun terjadi Pandemi maupun tidak, tidak menjadi dampak yang besar bagi kegiatan impor di Indonesia.Bahkan setelah Wuhan dinyatakan bebas dari Virus Corona ini kegiatan Impor untuk barang-barang non migas semakin membanjiri Indonesia.

Hasil penelitian ini juga sesuai dengan penelitian yang dilakukan oleh Putri \& Suhadak (2019) yang menyatakan bahwa pengaruh perang dagang Amerika Serikat dan China terhadap ekspor dan impor membuktikan bahwa tidak ada pengaruh secara signifikan impor Indonesia 
dari China sebelum dan sesudah terjadinya perang dagang Amerika Serikat dan China karena China memiliki banyak kepentingan ekonomi di Indonesia. Tentu mencari produk baru dan mengambil langkah berikutnya untuk antisipasi.

\section{KESIMPULAN}

Berdasarkan hasil penelitian pengaruh pandemic covid-19 terhadap ekspor dan impor Indonesia China periode Mei 2019 - Desemer 2020 dengan menggunakan uji beda paired sample test dapat di ambil kesimpulan bahwa terjadinya pandemic covid-19 di Indonesia pada bulan Maret 2020 memberikan hasil bahwa tidak ada perbedaan ekspor Indonesia ke China. Sebab Indonesia hanya menyumbangkan sedikit komoditas produk ekspor ke China.Begitu pula dengan kegiatan impor tidak ada perbedaan antara impor Indonesia dari China sebelum dan sesudah terjadinya Pandemi Covid-19.Hal ini disebabkan karena ketergantungan masyarakat Indonesia yang menggunakan barang-barang produksi dari China semakin menjadi tradisi pasar.Berdasarkan hasil penelitian diatas, maka dapat dikemukakan beberapa saran bagi penelitian selanjutnya yakni data yang peneliti gunakan hanyalah data ekspor dan impor non migas, disarankan agar penelitian lajutan untuk lebih memperluas data yang akan dianalisis agar lebih memberikan pemahaman yang lebih utuh kepada pembaca.

\section{DAFTAR PUSTAKA}

Badan Pusat Statistik. Ekspor dan Impor, diakses pada 28 Januari 2020 dari http://www.bps.go.id.

Ghozali, Imam. 2013. Aplikasi Analisis Multivariate dengan Program IBM SPSS 21. Semarang: Badan Penerbit Universitas Diponegoro.

Hamdani dan Arimbi, Pebriana. 2012. Ekspor Impor Tingkat Dasar Level I (Satu). Jakarta Timur: BUSHINDO.

Pambudy, A. P., \& Syairozi, M. I. (2019). Analisis Peran Belanja Modal dan Investasi Swasta Terhadap Pertumbuhan Ekonomi Serta Dampaknya Pada Kesejahteraan Masyarakat. Jurnal Ekonomi dan Bisnis, 20(1), 26-39.

Purwito, Ali. 2015. Ekspor, Impor, Sistem Harmonisasi, Nilai Pabean, Dan Pajak Dalam Kepabeanan. Jakarta: Mitra Wacana Media.

Putri, Acinta Bunga \& Suhadak.2019. Uji Beda Ekspor dan Impor Indonesia sebelum dan Sesudah terjadi perang Dagang Amerika Serikat dan China.Jurnal Administrasi Bisnis (JAB), 71 (1): 81-90

Rahmah Syahidah, Annisa. 2016. Pengaruh ASEAN-China Free Trade Area terhadap ekspor dan impor Indonesia-China. Jurnal Administrasi Bisnis, 39 (1): 73-80.

Sudijono, Anas. 2008. Pengantar Statistik Pendidikan. Jakarta: CV. Rajawali.

Suharyadi dan Purwanto. 2009. Statistika untuk Ekonomi dan Keuangan Modern. Jakarta: Salemba Empat.

Susanti, I., Syairozi, M. I., \& Lukman, H. Y. W. (2021). Analisis Sistem Manajemen Dalam Pengelolaan Bumdes Di Desa Bluluk. Jurnal Sains Sosio Humaniora, 5(2), 701-710.

Syairozi, M. I. (2011). Analisis peranan sektor pertanian terhadap produk domestik regional bruto (PDRB) di kabupaten Malang (periode 2000-2008) (Doctoral dissertation, Universitas Negeri Malang).

Welianto, Ari. 2020. Peran Indonesia dalam Kerjasama Antarnegara.https://www.kompas.com/skola/read/2020/07/04/151500569/peranindonesia-dalam-kerjasama-antarnegara-di-bidang-ekonomi?page=2, Kompas.com, diakses pada tanggal 30 Januari 2021. 
Perdana, Hana, Adi. 2020. Ekspor-Impor Indonesia dengan Tiongkok. https://www.idntimes.com/business/economy/hana-adi-perdana-1/ekspor-importerbesar-indonesia-dengan-tiongkok/3, IDNTIMES, diakses tanggal 30 Januari 2021. 